\title{
Fermentation characteristics and nutritive value of sweet sorghum silage with Paiaguas palisadegrass and Ipypora grass
}

\section{Características fermentativa e valor nutritivo da silagem de sorgo sacarino com capins Paiaguás e Ipyporã}

\author{
Nariane Coelho de Oliveira ${ }^{1 *}$; Kátia Aparecida de Pinho Costa²; Laíne Gonçalves \\ Rodrigues3; Ana Carolina Gomes Silva3; João Victor Campos Pinho Costa3; \\ Sabryna Álex Almeida Silva ${ }^{3}$; Luiz Felipe Aprígio de Assis; \\ Stella Mendes Pio de Oliveira ${ }^{4}$; Milena de Lima Vieira ${ }^{1}$
}

\section{Highlights}

Addition forages to silage decreased the DM content and increased the $\mathrm{pH}$ of silage. Increasing the level of forages in sorghum silage increased CP and digestibility. Addition of Paiaguas palisadegrass in silage resulted in higher CP and digestibility. Mixed silage represents a way to improve the quality of sorghum silage.

\begin{abstract}
Ensiling sorghum with tropical forages has been shown to be a promising alternative for ruminant feed production, as this approach improves the quality of the sorghum silage. In this context, the goal of this study was to evaluate the fermentation characteristics and nutritive value of sweet sorghum silage made with different levels of Paiaguas palisadegrass and Ipypora grass. The experiment was conducted in a completely randomized $2 \times 6$ factorial design with four replications. Two forages (Paiaguas palisadegrass and Ipypora grass) were added to sorghum at six levels $(0,20,40,60,80$ and 100\%), for a total of 48 experimental silos. After 50 days of fermentation, the silos were opened, and the fermentation profile and chemical composition of the silage were analysed. The results showed that the addition of Paiaguas palisadegrass and Ipypora grass to the sorghum silage increased the $\mathrm{pH}$, buffering capacity and $\mathrm{NH}_{3}-\mathrm{NT}$ of the silage and reduced its

1 Students of the Graduate Program in Animal Science, Goiano Federal Institute, Rio Verde, GO, Brazil. E-mail: narianecoelho@gmail.com; vieiramilenalima@gmail.com

2 Profa and Researcher Graduate Program in Agricultural Sciences/Agronomy and Animal Science, Goiano Federal Institute, Rio Verde, GO, Brazil, CNPq Scholarship. E-mail: katia.costa@ifgoiano.edu.br

${ }^{3}$ Undergraduate Students in Animal Science, Goiano Federal Institute, Rio Verde, GO, Brazil. E-mail: anacarolinagomes68@gmail.com; joaovictorcamposjv98@gmail.com; lainerodrigues16@gmail.com; sabrynarv@ hotmail.com; luizfelipeassis94@gmail.com

${ }^{4}$ Student of the Graduate Program in Agricultural Sciences/Agronomy, Goiano Federal Institute, Rio Verde, GO, Brazil. E-mail: stellamendesp@hotmail.com

* Author for correspondence
\end{abstract}

Received: Oct. 27, 2020 - Approved: Feb. 03, 2021 
dry matter content but did not affect its fermentation characteristics, which remained within an appropriate range. The addition of increasing levels of Paiaguas palisadegrass and Ipypora grass to the sorghum silage increased the crude protein and in vitro dry matter digestibility (IVDMD) of the silage and decreased the fibre fraction (neutral detergent fibre, acid detergent fibre and lignin) and ether extract contents. Adding tropical forages to sorghum silage material at levels above $40 \%$ is recommended. Among forage crops, addition of Paiaguas palisadegrass to sorghum silage resulted in higher content of crude protein and IVDMD. Mixed silages can be an effective alternative to improve the quality of forage sorghum silage.

Key words: Brachiaria. Buffering capacity. Fibre fractions. Ammonia nitrogen. Crude protein. Sorghum bicolor Moench.

\section{Resumo}

A cultura do sorgo ensilado com forrageiras tropicais, vem se mostrando alternativa promissora de alimentação para a produção de ruminantes, por proporcionar melhorias na qualidade da silagem. Neste contexto, objetivou-se avaliar as características fermentativa e valor nutritivo da silagem de sorgo sacarino com níveis de capins Paiaguás e Ipyporã. O experimento foi conduzido no delineamento experimental inteiramente casualizado, com quatro repetições, em esquema fatorial $2 \times 6$, sendo duas forrageiras (Paiaguás e Ipyporã) adicionados ao sorgo em seis níveis (0; 20; 40; 60, 80 e 100\%), totalizando 48 silos experimentais. Após 50 dias de fermentação, os silos foram abertos para realização das análises do perfil fermentativo e composição bromatológica. Os resultados mostraram que a adição dos capins Paiaguás e Ipyporã na ensilagem de sorgo aumentou o pH, capacidade tampão e $\mathrm{N}-\mathrm{NH}_{3}$ e, reduziu os teores de matéria seca, mas não comprometeu as características fermentativas das silagens, ficando dentro do padrão adequado. A adição de níveis crescente de capins Paiaguás e Ipyporã na ensilagem de sorgo aumentou os teores de proteína bruta e digestibilidade in vitro da matéria seca (DIVMS) e diminuiu as frações fibrosas (fibra em detergente neutro, fibra em detergente ácido e lignina) e extrato etéreo, sendo recomendando níveis cima de $40 \%$. Entre as forrageiras, a adição de capim-paiaguás na ensilagem de sorgo apresentou maior teor de proteína bruta e DIVMS. Silagens mistas podem ser uma alternativa eficaz para melhorar a qualidade da silagem exclusiva de sorgo sacarino.

Palavras-chave: Brachiaria. Capacidade tampão. Frações fibrosas. Nitrogênio amoniacal. Proteína bruta. Sorghum bicolor Moench.

\section{Introduction}

In the seasonal cycles of pastures, tropical forage plants do not provide enough nutrients to meet the requirements of pastured animals during the dry season (Daniel, Bernardes, Jobim, Schmidt, \& Nussio 2019). Therefore, the demand for alternative roughage, such as silages, has grown (Quintino et al., 2016).
Sorghum is one of the fastest growing crops in Brazil and has strategic importance with regard to grainand forage supplies. Cereals contribute directly to the balance of regulatory stocks of energy grains, forage production, sustained livestock growth, and food supplies, thus contributing to cost reductions and allowing greater competitiveness in the grain production sector (Costa et al., 2016b). 
Sorghum is a good choice for production because it is a hardy plant that tolerates hot climates and is resistant to soil and climate variations and tolerant to abiotic stresses such as water deficiency, salinity and waterlogging; moreover, it has low soil fertility demands (Teetor et al., 2011). Another positive characteristic of sorghum is of its potential for regrowth, with production that can reach up to $60 \%$ of its potential in the first cut when subjected to proper management (Cruz et al., 2020). Therefore, sorghum has many advantages for use as a source of animal food to produce grains and nutritious forage.

Regarding silage production, sweet sorghum stands out in relation to other crops due to its potential to produce a large amount of forage with characteristics that favour the silo fermentation process and without the need for large amounts of inoculants or additives; sorghum produces silage with good acceptability (Cruz et al., 2020). However, as it is a tall crop, it has a high fibre fraction in the stem (Cruz et al., 2020), which can interfere with its consumption by animals. In addition, Chen, Dong, Li and Shao (2019) reported that sweet sorghum alone could not fully meet the production requirements of growing or lactating ruminants as a result of a lack of crude protein.

On the other hand, silage made from tropical forages is also becoming more popular for livestock production. The advantages of producing tropical forage silage are related to its high annual production per area, perennial growth cycle, and low risk of loss; tropical forages also have greater harvest flexibility and higher crude protein content than corn and sorghum, which are the most commonly used silage crops and have averaged of 60 and $80 \mathrm{~g} \mathrm{~kg}^{-1}$ DM CP, respectively (Quintino et al.,
2016). Nevertheless, tropical forages, have a low content of dry matter at the time of cutting which, along with their low content of soluble carbohydrates, can affect fermentation and compromise the final silage quality (Negrão et al., 2016).

Among the various tropical forage options, we highlight Paiaguas palisadegrass, which has good yield, good vigour, a high leaf:stem ratio and good nutritional value ( $R$. R. G. F. Costa et al., 2018). The hybrid BRS Ipypora, introduced in 2017, is the result of a cross between Brachiaria ruziziensis and Brachiaria brizantha and is considered an important forage alternative for pasture-based animal production systems due to its quality as forage. Both cultivars have an average of 110 - $130 \mathrm{~g} \mathrm{~kg}^{-1}$ DM crude protein (Echeverria et al., 2016; Euclides et al., 2018; Epifanio et al., 2019).

In this context, mixed forage-sorghum silage with Paiaguas palisadegrass and Ipypora grass could provide benefits such as balancing the nutritional value of pure sorghum silage by increasing the crude protein content and digestibility and allowing greater flexibility of use due to the ease of using the ensiled mass in pastures of established tropical forages.

In addition, since these are Brachiaria cultivars that were recently made available on the market, it is necessary to generate more information about which forage is more suitable for ruminants and the appropriate level of addition to sorghum silage to provide better silage quality. This information will enable their use as an alternative to feed ruminants more efficiently. Thus, the goal of this study was to evaluate the fermentation characteristics and nutritive value of sweet sorghum silage with different levels of Paiaguas palisadegrass and Ipypora grass. 


\section{Material and Methods}

The experiment was carried out at the Federal Institute Goiano, Campus Rio Verde, in Dystrophic Red Latosol (Santos et al., 2018). Soil samples were collected at a $0-20 \mathrm{~cm}$ depth before the beginning of the experiment for physicochemical analysis, with following characteristics: 562; 94 and $344 \mathrm{~g} \mathrm{~kg}^{-1}$ of clay, silt and sand contents, respectively; $\mathrm{pH}_{\text {in }} \mathrm{CaCl}_{2}$ : 5.8; Ca: $1.8 \mathrm{cmol}_{\mathrm{c}} \mathrm{dm}^{-3} ; \mathrm{Mg}: 1.1 \mathrm{cmol}_{\mathrm{c}} \mathrm{dm}^{-3} ; \mathrm{Al}^{2}$ $0.0 \mathrm{cmol}_{\mathrm{c}} \mathrm{dm}^{-3} ; \mathrm{Al}+\mathrm{H}: 2.9 \mathrm{cmol}_{\mathrm{c}} \mathrm{dm}^{-3} ; \mathrm{K}: 0.53$ $\mathrm{cmol}_{\mathrm{c}} \mathrm{dm}^{-3}$; CEC (cation exchange capacity): $6.33 \mathrm{cmol}_{\mathrm{c}} \mathrm{dm}^{-3} ; \mathrm{V} 1: 54.20 \% ; \mathrm{P}$ (Mehlich): 3.6 $\mathrm{mg} \mathrm{dm}^{-3}$; Cu: 0,61 mg dm-3, Zn: 3,83 mg dm-3; Fe: $32,5 \mathrm{mg} \mathrm{dm}^{-3}$ and OM: $24.37 \mathrm{~g} \mathrm{~kg}^{-1}$.

Soil preparation started in November 2018, eliminating weeds by applying glyphosate and 2,4-D. Thirty days after desiccation, harrowing was carried out with a plowing harrow, followed by a leveling harrow. A week before sowing, another leveling harrowing operation and sowing furrows were made using a seeder.

Sorghum was planted in February 2019, with an inter-row spacing of $50 \mathrm{~cm}$. Twelve seeds were planted per meter, sown at $2 \mathrm{~cm}$ depth. The hybrid used was BRS 506, a tall (around 2.5 meters) variety of high mass productivity. Plots were composed of eight rows, three meters long.

Upon sowing, $180 \mathrm{~kg} \mathrm{ha}^{-1} \mathrm{P}_{2} \mathrm{O}_{5}$ and 20 $\mathrm{kg} \mathrm{ha}^{-1} \mathrm{FTE}$ BR 12 were applied in the planting furrow (9\% Zn; 1.8\% B; 0.8\% Cu; 2\% Mn; 3.5 $\% \mathrm{Fe}$ and $0.1 \% \mathrm{Mo})$, as single superphosphate and fritted trace elements (FTE's), respectively. When sorghum plants were at the stage of three and six leaves, broadcast topdressing was performed with 80 and $60 \mathrm{~kg} \mathrm{ha}^{-1}$ nitrogen (N) and $\mathrm{K}_{2} \mathrm{O}$ as urea and potassium chloride, respectively.
The experiment was conducted in a 2 x 6 factorial completely randomized design, with four replications, two forages (Paiaguas palisadegrass and Ipypora grass) added to sorghum in six levels $(0 ; 20 ; 40 ; 60,80$ and $100 \%)$, totaling 48 experimental silos.

Paiaguas palisadegrass and Ipypora grass were harvested in areas already established for crop-livestock integration experiments, planted in February 2019. Thirty days before cutting for silage making, grasses received nitrogen and potassium fertilization at a dose of 80 and $40 \mathrm{~kg} \mathrm{ha}^{-1}$, respectively, as urea and potassium chloride.

For silage making, sweet sorghum was harvested at 100 days of development at the milky/soft dough stage with $332.9 \mathrm{~g}$ kg dry matter (DM) and grasses within the development cycle, with an average height of 78 and $67 \mathrm{~cm}$, and 239.4 and $241.3 \mathrm{~g} \mathrm{~kg} \mathrm{DM}$ for Paiaguas palisadegrass and Ipypora grass, respectively. Both crops were harvested at 20 $\mathrm{cm}$ above the soil level using a manual brush cutter. Subsequently, forages were chopped separately to approximately $10 \mathrm{~mm}$ of particle length using a stationary forage chopper.

The material was homogenized according to each levels of each forage and stored in experimental PVC tube silos measuring $10 \mathrm{~cm}$ in diameter and $40 \mathrm{~cm}$ in length. Subsequently, the material was compacted with an iron pendulum, and silos were closed with PVC lids and sealed with adhesive tape to prevent air exposure. The mean silage density was approximately 583.37 $\mathrm{kg} \mathrm{dm}^{-3}$. In the silos they contained sand and mesh at the bottom to quantify the losses by effluent and were weighed before and after the ensiling to quantify the losses by gases (Jobim, Nussio, Reis, \& Schmidt 2007). The 
experimental silos were stored in a covered area at room temperature.

The fresh material (before ensiling) was analysed (Table 1) for dry matter (DM), crude protein (CP), lignin, ether extract (EE) and ash contents according to the methodologies described by the Association Official Analytical Chemists [AOAC] (1990). Neutral detergent fibre (NDF) and acid detergent fibre (ADF) were estimated by the method described by Mertens (2002). The content of total digestible nutrients (TDN) was calculated using the equation of Cappelle, Valadares, Silva and Cecon (2001). The in vitro dry matter digestibility (IVDMD) was analysed using the technique described by Tilley and Terry (1963), which was adapted to the artificial rumen developed by ANKOM $^{\circledR}$ (Daisy Incubator - in vitro true digestibility). Donor animals were found in pasture of Paiaguas palisadegrass.
The silos were opened after 56 days of fermentation, discarding the silage at the top and bottom of each silo. Samples from the middle of each silo were homogenized and placed in plastic trays. A portion of the fresh silage was separated for analysis of fermentative parameters, such as buffering capacity, $\mathrm{pH}$ and ammonia nitrogen as a percentage of total nitrogen $\left(\mathrm{N}-\mathrm{NH}_{3} / \mathrm{NT}\right)$, following the method described by Bolsen et al. (1992).

The $\mathrm{pH}$ and buffering capacity analyzes were performed at the moment of opening the silos, thus avoiding changes in the expected values caused by heat and humidity. For ammoniacal nitrogen, the silage was frozen to inactivate the activities of the anaerobic bacteria to prevent the loss of nitrogen by volatilization, and later the analyzes were performed. Gas and effluent losses were determined by the methodology of Jobim et al. (2007).

\section{Table 1}

Chemical composition ( $\mathrm{g} \mathrm{kg}^{-1} \mathrm{DM}$ ) of sweet sorghum, Paiaguas palisadegrass and Ipypora grass before ensiling (on a green basis)

\begin{tabular}{|cccc|}
\hline Chemical composition & Sweet sorghum & Paiaguas palisadegrass & Ipypora grass \\
\hline DM & 332.9 & 239.4 & 241.3 \\
\hline CP & 78.8 & 155.2 & 147.1 \\
\hline Ash & 461.2 & 488.3 & 470.8 \\
\hline NDF & 676.6 & 651.2 & 649.2 \\
\hline ADF & 409.8 & 350.9 & 358.2 \\
\hline Lignin & 248.5 & 189.3 & 187.4 \\
\hline IVDMD & 581.2 & 623.6 & 619.3 \\
\hline EE & 311.5 & 191.3 & 193.5 \\
\hline TDN & 598.2 & 588.9 & 590.4 \\
\hline
\end{tabular}

DM: dry matter; CP: crude protein; NDF: neutral detergent fibre; ADF: acid detergent fibre; EE: ether extract; IVDMD: in vitro dry matter digestibility; and TDN: total digestible nutrients. 
The other portion of the material (approximately $0.5 \mathrm{~kg}$ ) was weighed and oven-dried at $55^{\circ} \mathrm{C}$ for 72 hours. Then, the samples were ground in mill to pass through a 1-mm sieve and stored in plastic bags for later analysis of the chemical composition, according to the methodology described above.

Data were tested by analysis of variance, considering forage, levels and the interaction between factors as sources of variation. Mean values were compared by Tukey's test at 5\% probability. Forage levels were evaluated by regression analysis, with standard error of the mean, using the Sigma Plot software.

\section{Results and Discussion}

There was no significant effect ( $p>$ 0.05) of forage type (Table 2) or the interaction of forage type and level on the $\mathrm{pH}$, buffering capacity, dry matter, $\mathrm{NH}_{3}-\mathrm{N} / \mathrm{TN}$ and effluent losses (Figure 1). However, the forage addition level had a significant effect $(p<0.05)$ on these variables. For forage, addition level and their interaction had no effects $(p>0.05)$ on gas losses.

\section{Table 2}

Fermentation characteristics of sorghum silage with forage

\begin{tabular}{cccccc} 
Forage & $\mathrm{pH}$ & $\begin{array}{c}\mathrm{BC} \\
\text { (eq.mg g-1 DM) }\end{array}$ & $\begin{array}{c}\mathrm{DM} \\
\left(\mathrm{g} \mathrm{kg}^{-1}\right)\end{array}$ & $\begin{array}{c}\mathrm{N}^{-\mathrm{NH}_{3}} / \mathrm{NT} \\
\left(\mathrm{g} \mathrm{kg}^{-1}\right)\end{array}$ & $\begin{array}{c}\mathrm{EL} \\
\left(\mathrm{kg} \mathrm{t}^{-1} \mathrm{GM}\right)\end{array}$ \\
\hline Paiaguas palisadegrass & $4.04 \mathrm{a}$ & $111.56 \mathrm{a}$ & $288.78 \mathrm{a}$ & $30.62 \mathrm{a}$ & 8.94 \\
Ipypora grass & $4.07 \mathrm{a}$ & $110.98 \mathrm{a}$ & $286.65 \mathrm{a}$ & $29.41 \mathrm{a}$ & 9.03 \\
Average & 4.06 & 111.27 & 287.71 & 30.02 & 8.99 \\
SEM & 0.014 & 1.840 & 1.964 & 0.262 & 0.139 \\
P value & 0.184 & 0.825 & 0.452 & 0.643 & 0.381
\end{tabular}

Means followed by the same letter do not differ significantly by Tukey's test ( $p>0.05$ ).

BC: buffering capacity; DM: dry matter; EL: effluent losses

SEM: standard error of mean.

Evaluating the $\mathrm{pH}$ results (Figure 1a) revealed a linear increase in the $\mathrm{pH}$ value as the grass level in the ensiled mass increased. Sorghum silage had a $\mathrm{pH}$ of 3.7 , while the silage with $100 \%$ grasses had a pH of 4.2 , representing an increase of $15 \%$ in relation to the pure sorghum silage. The increase in $\mathrm{pH}$ with the increase in forage level can be explained by the higher buffering capacity of forages (Figure 1b). This higher buffering capacity is due to the greater amount of buffering substances generated by proteolysis in forages; proteolysis releases ammonia, which makes it difficult to decrease the pH (Zhang et al., 2016). Nevertheless, it is worth mentioning that even with an increase in $\mathrm{pH}$ caused by the increase in the forage addition level, the $\mathrm{pH}$ values were still close to the appropriate range, which, according to McDonald, Henderson and Heron (1991), should be between 3.8 and 4.2. These are considered acceptable values for well- 
preserved silages because this $\mathrm{pH}$ range inhibits the growth of enterobacteria and clostridia. The $\mathrm{pH}$ levels found in this study are acceptable, as they guarantee good silage preservation characteristics (Chen et al., 2019).

The increase in the proportion of forage in silage also resulted in higher values for the buffering capacity (Figure 1b), showing a linear increase up to the maximum dose of forage. This occurred because tropical forages have a higher buffering capacity than annual crops (Souza et al., 2019). According to S. S. Oliveira et al. (2020), forage grasses have a high buffering capacity and a low content of soluble carbohydrates; this can influence $\mathrm{pH}$ values, as observed in this study.

Corroborating these results, Costa et al. (2018) evaluated millet and Paiaguas palisadegrass silage in monocrop and mixed systems under different forage systems and reported that millet silage in the monocrop system showed a lower buffering capacity than Paiaguas palisadegrass, which had the highest value. Behling Neto et al. (2017) found that the lowest values for buffer capacity may have been observed for cultivars of sweet sorghum (BRS 506) in the first harvest due to the lower amounts of ash and crude protein in sorghum than in the other tested silages; this result is in accordance with the results for the pure sorghum silage in the present study.

Like the $\mathrm{pH}$ and buffering capacity, $\mathrm{NH} 3 / \mathrm{TN}$ also increased with increasing forage level in the sorghum silage (Figure $1 \mathrm{c}$ ).
However, the mean value at the $100 \%$ dose was $40.80 \mathrm{~g} \mathrm{~kg}^{-1} \mathrm{NH}_{3}$-TN. According to (Kung, Shaver, Grant, \& Schmidt, 2018), this value is considered to be within the ideal range to provide adequate lactic fermentation, reduce proteolysis and inhibit the growth of undesirable microorganisms; silage should contain levels of NH3-NT below $100 \mathrm{~g} \mathrm{~kg}^{-1}$. Thus, the levels found in this study are in line with the results obtained by R. F. Costa et al. (2016a) and Behling Neto et al. (2017). This result shows that even with the addition of forages, there was little activity of Clostridium bacteria; consequently, there was no excessive deterioration of proteins, and the nutritional value of the silage was not compromised.

Figure 1 (d) shows a decrease in DM content as the grass forage levels increased in the sorghum silage. This was due to the low DM content of Paiaguas palisadegrass $\left(239.4 \mathrm{~g} \mathrm{~kg}^{-1}\right)$ and Ipypora grass $\left(241.3 \mathrm{~g} \mathrm{~kg}^{-1}\right)$ at the time of cutting. Typically, tropical grass silages have high moisture levels at the ideal cutting time (Souza et al., 2019; Oliveira et al., 2020; Paludo et al., 2020). Similar results were reported by S. S. Oliveira et al. (2020), who evaluated the fermentation parameters of sorghum intercropped with Paiaguas palisadegrass in different forage systems and at different maturity stages and found that Paiaguas palisadegrass silage showed a higher $\mathrm{pH}$ and buffering capacity and a lower DM content than sorghum silage. However, the combination of sorghum and Paiaguas palisadegrass resulted in better silage fermentation parameters. 
(a)

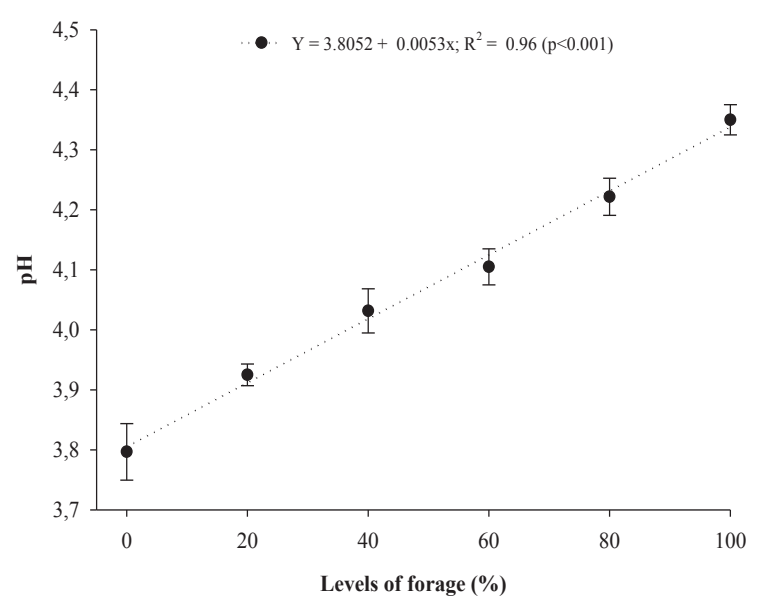

(c)

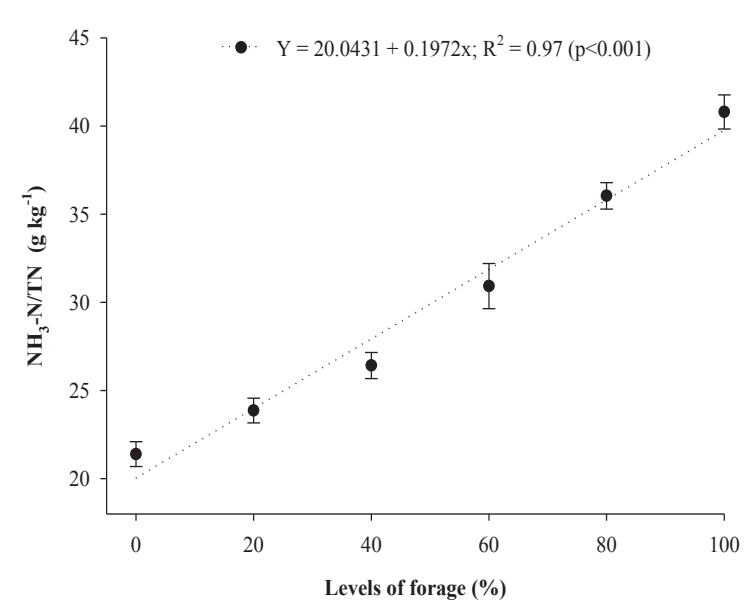

(b)

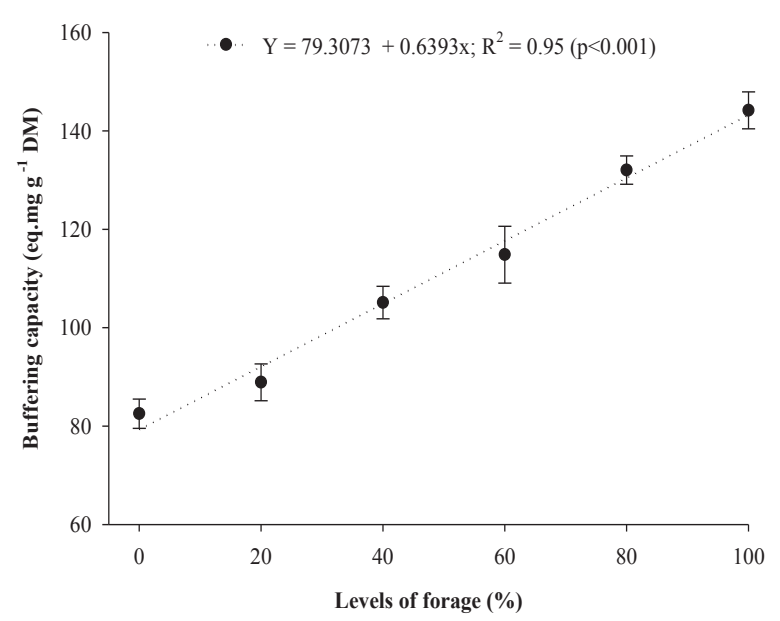

(d)

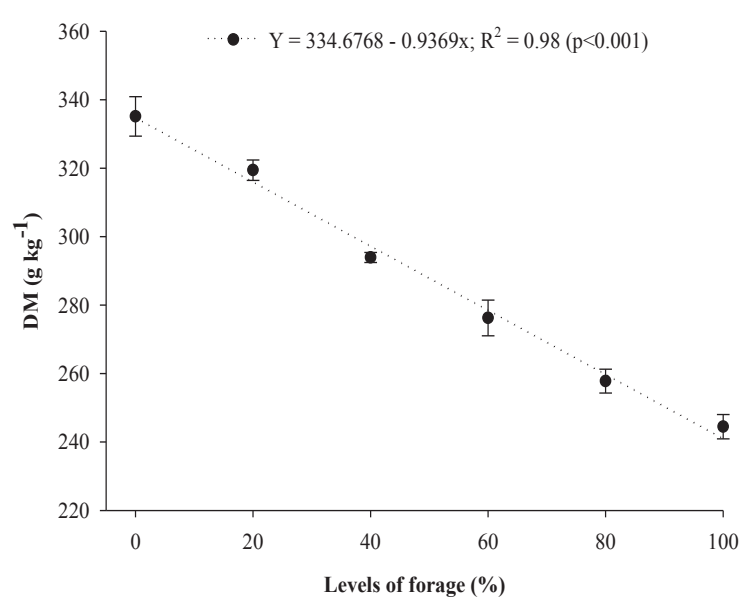

(e)

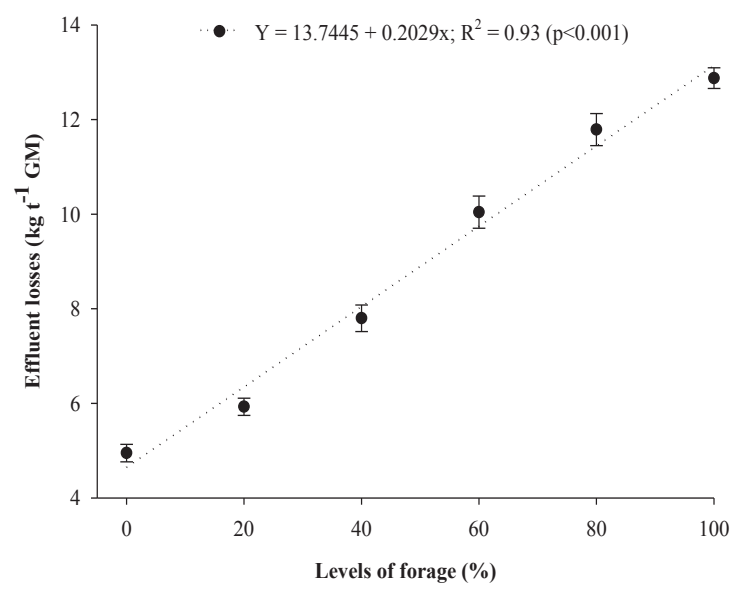

Figure 1. Fermentation characteristics of sorghum silage with different levels of forage. Vertical bars indicate the standard deviation from the mean. 
According to Chen et al. (2019), the DM content of silage tends to decrease consistently throughout the silage process because the easily degradable constituents of silage are broken down into silage acids, ethanol and carbon dioxide by microorganisms during silage fermentation. The ideal DM content of forages to ensure adequate fermentation inside the silo is $300 \mathrm{~g} \mathrm{~kg}^{-1}$ to 350 $\mathrm{g} \mathrm{kg}^{-1}$ (McDonald et al., 1991).

The DM content is a major factor affecting fermentation during ensiling and, consequently, the quality of the silage produced; it is also positively correlated with intake (McDonald et al., 1991). Therefore, it is important to produce mixed silages to balance the DM content of the ensiled material.

Effluent losses were also influenced by the level of forage in the silage (Figure 1e). This was due to the lower DM contents of Paiaguas palisadegrass and Ipypora grass, which resulted in higher effluent losses. In contrast in the pure sorghum silage, effluent losses were lower due to the higher DM content at the time of cutting $\left(332.9 \mathrm{~g} \mathrm{~kg}^{-1}\right)$. Gomes et al. (2019) reported that the volume of effluent produced in a silo is influenced mainly by the DM content of the ensiled forage species and the degree of compaction.
According to L. S. O. Ribeiro et al. (2010), effluent loss implies the loss of nutrients that are leached to the bottom of the silo, leaving the ensiled mass with a lower content of soluble nutrients than the fresh material. Tropical forages with DM contents below $25 \%$ can have high effluent losses, which decreases the nutritional value of silage because the effluents include some carbohydrates and nitrogen (Kung et al., 2018). Thus, attention should be paid to the need for mixed silage to reduce moisture levels in tropical forage silage and, consequently, reduce effluent losses.

In general, the characteristics of sorghum favour an effective fermentation process, such as its adequate DM content (300 to $350 \mathrm{~g} \mathrm{~kg}^{-1}$ ), soluble carbohydrate level greater than $150 \mathrm{~g} \mathrm{~kg}^{-1}$ and buffering power of less than 200 eq.mg HCl/100 g DM (Quintino et al., 2016). These characteristics contribute to minimizing the problems related to the fermentation of pure grass silages.

The interaction of forage type and addition level had a significant effect $(p<0.05)$ on the crude protein and digestibility of silages (Figure 2). However, only the forage addition level (Figure 3), not the forage type ( $p>0.05)$, had a significant effect $(p<0.05)$ on the contents of NDF, ADF, lignin and ether extract (Table 3). The values of ash and TDN were not influenced by the different addition levels and forage or their interaction. 
(a)

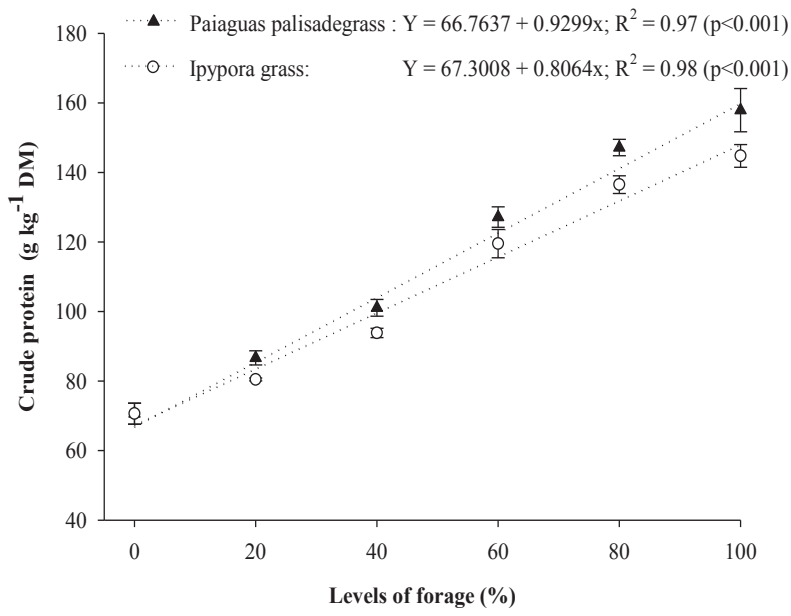

(b)

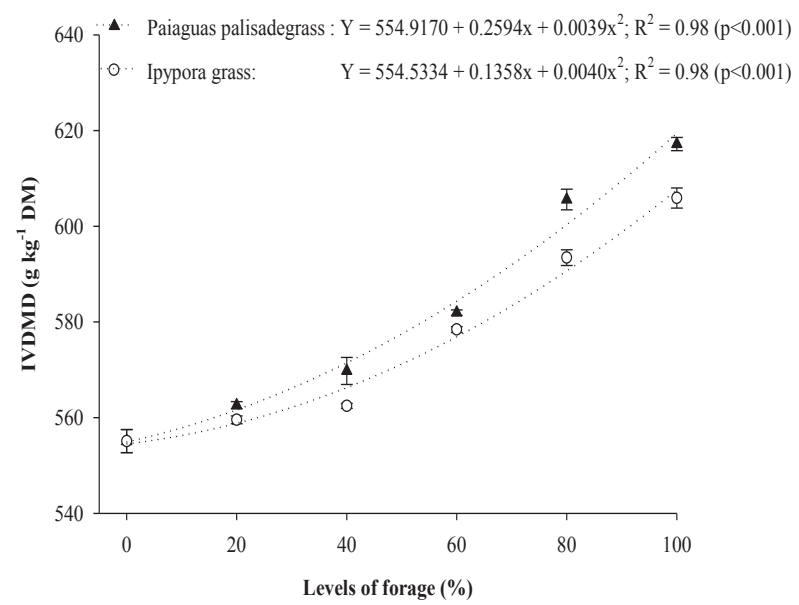

Figure 2. Crude protein content (a) and digestibility (b) of sorghum silage with different levels of forage. Vertical bars indicate the standard deviation of the mean.

There was a linear increase in the crude protein level of the silage with the increasing level of forage addition in the ensiled material (Figure 2 a). This is relevant to increasing the crude protein of sweet sorghum silage and resulted in better nutritional quality in the mixed silage. One of the main advantages of producing mixed silages is the increase in crude protein content and digestibility. Sweet sorghum silage is considered an energy food; however, its protein content is low $(70.64 \mathrm{~g}$ $\left.\mathrm{kg}^{-1} \mathrm{DM}\right)$, which is a disadvantage of sorghum silage compared to tropical forage silages. Evaluating bagasse silages from sweet sorghum cultivars, Gomes-Rocha et al. (2018) observed crude protein contents from 60.5 to $70.1 \mathrm{~g} \mathrm{~kg}^{-1} \mathrm{DM}$, which are close to those found in the present study in the pure sorghum silage.

Between the two forage silages, the $100 \%$ Paiaguas palisadegrass silage had a $12 \%$ higher crude protein than the $100 \%$ Ipypora grass silage. This was due to the morphological structure of Paiaguas palisadegrass, which has a high leaf:stem ratio than Ipypora grass and thus generates better-quality forage (Epifanio et al., 2019; Souza et al., 2019). 
Table 3

NDF, ADF, lignin and ether extract contents of sorghum silage with forages

\begin{tabular}{ccccc|}
\hline Forage & $\begin{array}{c}\text { NDF } \\
\left(\mathrm{g} \mathrm{kg}^{-1} \mathrm{DM}\right)\end{array}$ & $\begin{array}{c}\text { ADF } \\
\left(\mathrm{g} \mathrm{kg}^{-1} \mathrm{DM}\right)\end{array}$ & $\begin{array}{c}\text { Lignin } \\
\left(\mathrm{g} \mathrm{kg}^{-1} \mathrm{DM}\right)\end{array}$ & $\begin{array}{c}\mathrm{EE} \\
\left(\mathrm{g} \mathrm{kg}^{-1} \mathrm{DM}\right)\end{array}$ \\
\hline Paiaguas palisadegrass & $695.72 \mathrm{a}$ & $371.71 \mathrm{a}$ & $21.28 \mathrm{a}$ & $25.34 \mathrm{a}$ \\
Ipypora grass & $700.74 \mathrm{a}$ & $375.67 \mathrm{a}$ & $21.57 \mathrm{a}$ & $24.93 \mathrm{a}$ \\
Average & 698.23 & 373.69 & 21.43 & 25.13 \\
SEM & 1.530 & 1.870 & 0.141 & 0.343 \\
P value & 0.340 & 0.148 & 0.175 & 0.442
\end{tabular}

Means followed by the same letter do not differ significantly by Tukey's test ( $p>0.05)$.

SEM: standard error of mean

NDF: neutral detergent fibre; ADF: acid detergent fibre; EE: ether extract.

The addition of increasing levels of Paiaguas palisadegrass and Ipypora grass resulted in a linear increase in the IVDMD of the sorghum silage (Figure 2 b) despite the fact that sorghum contains a higher content of non-structural carbohydrates (starch, pectin and sugars) than of structural carbohydrates, which are normally less digestible (Van Soest, 1994). This can be explained by the higher crude protein content and lower fibre fractions of the forages, which contributed to the better digestibility of the silage. The IVDMD values obtained here are consistent with the values found in other studies (Skonieski et al., 2010; Cruvinel et al., 2017; S. S. Oliveira et al., 2020; Taveira et al., 2020).

Of the two forage crops, Paiaguas palisadegrass provided higher values of IVDMD at all levels of addition. However, the difference was small, e.g., only $1.8 \%$ higher than that of Ipypora grass at the $100 \%$ level. This was due to the similarities between these two species of Brachiaria, which have a high proportion of leaves and high forage quality (Euclides et al., 2018; Epifanio et al., 2019).

Paiaguas palisadegrass and Ipypora grass are very productive forages that have excellent nutritional value (Table 1). In the present study, the forages were harvested during their development cycle, which contributed to maintaining their nutritional value. Echeverria et al. (2016) reported that the Ipypora grass hybrid is an important forage alternative for animal production systems due to its forage quality, specifically its vigour and the high number of leaves on each stem. In addition, this hybrid grows in small clumps with high basal tillering rates; low stolon emergence; and thin, short stems and is a forage with high nutritional value (Euclides et al., 2018).

There was a linear reduction in the contents of NDF, ADF and lignin with the increasing level of forage in the silage (Figure $3 a, b, c)$, i.e., a dilution of the fibre content. In comparison to the pure sorghum silage, the silage made of $100 \%$ forages had $8.6,23.6$ and $35.4 \%$ lower NDF, ADF and lignin contents, respectively. Sweet sorghum is tall, produces more stem biomass and less grain biomass than certain forages, and accumulates many of the fibre fractions in its stems (Taveira et al., 2020). This explains the higher values in the sorghum silage than in the forage silage in the 
present study. The non-significant differences ( $p>0.05$ ) between the fibre contents of the forages may be due to the similar levels

(a)

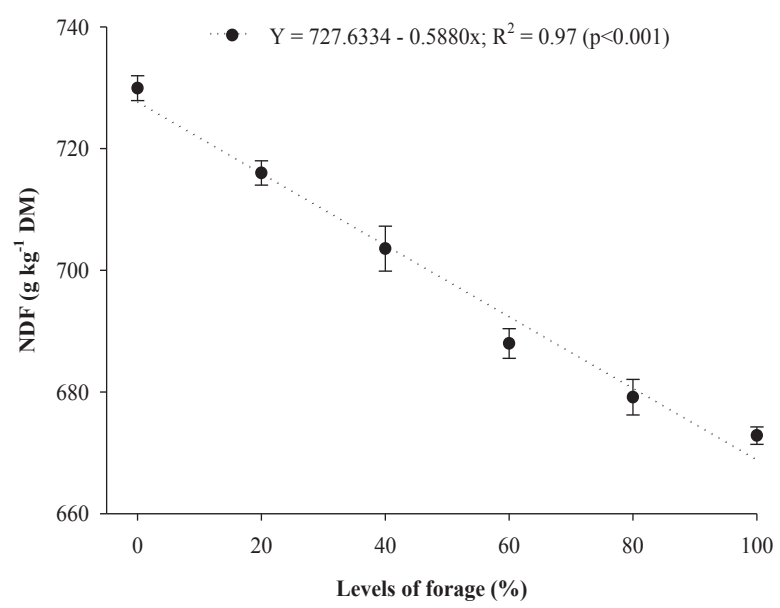

(c)

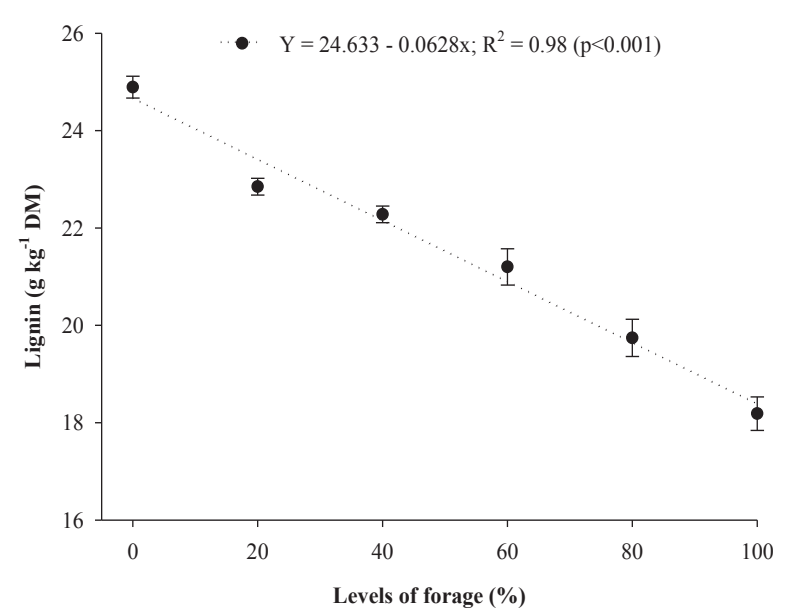

of the different fibre fractions in Paiaguas palisadegrass and Ipypora grass (Table 1) at the time of cutting.

(b)

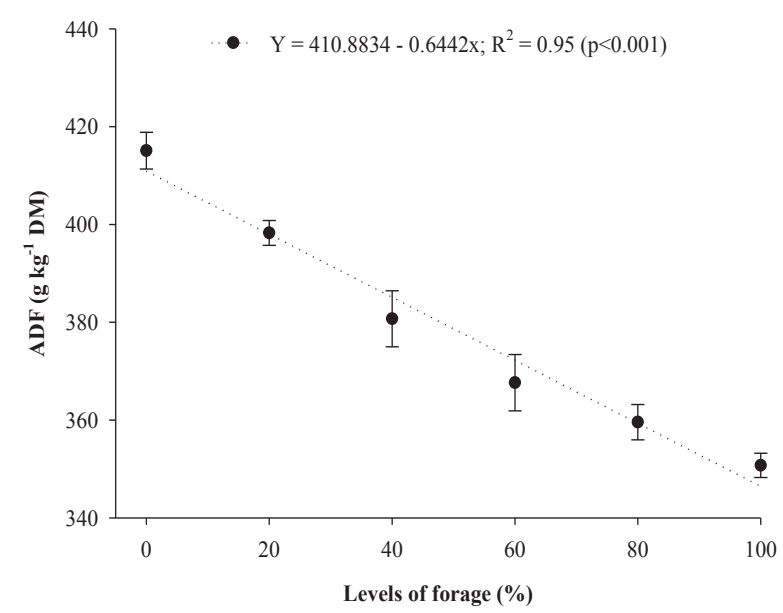

(d)

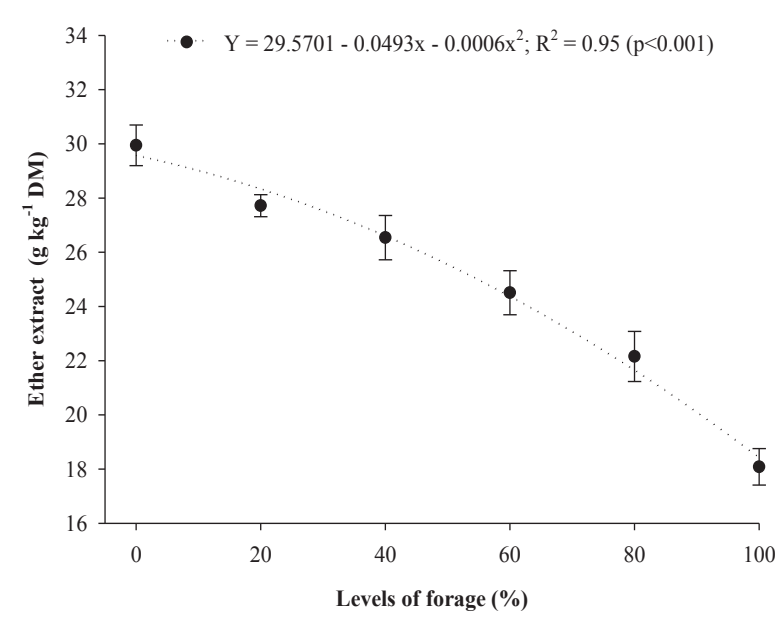

Figure 3. NDF (a), ADF (b), lignin (c), and ether extract (d) contents of sorghum silage with different levels of forage.

Vertical bars indicate the standard deviation of the mean.

Fibre fractions are important for characterizing the nutritional value of forages. The NDF content is directly related to animal intake, and the ADF indicates digestibility (Van Soest, 1994). Thus, high contents of NDF and
ADF are negatively correlated with the intake and digestibility of dry matter, and the higher contents of these fractions in the sorghum stem directly influence the silage composition, as observed by R. F. Costa et al. (2016a). 
For the ether extract (Figure $3 \mathrm{~d}$ ), there was a quadratic reduction in values with the increasing level of grass in the silage. This can be explained by the lower fat content of tropical forages (Table 1) than of sorghum. According to Bueno, Lazzari, Jobim and Daniel (2020), lipids are not typical fuels for fermentation; thus, well-preserved silages have levels of ether extract that are similar to those in fresh material. This finding is in line with the results of the present study.

The content of ether extract in silage is important for ruminant nutrition, as it is necessary to coordinate protein and energy levels for good ruminal function and nutrient use (L. B. D. Oliveira et al., 2010). The ether extract refers to the amount of oil present in the food, and an adequate amount of oil (up to $100 \mathrm{~g} \mathrm{~kg}^{-1} \mathrm{DM}$ ) is desirable because the energy provided by oil is greater than that provided by protein (Marafon et al., 2015). According to Ferreira et al. (2016), silages with lipid contents provide a feeling of satiety and greater energy gain than silages with low lipid contents. These findings emphasize the importance of mixed silage production to balance silage nutrient levels.

The TDN content of the silages was not influenced by the addition level, forage type or their interaction, and its average value was $600.18 \mathrm{~g} \mathrm{~kg}^{-1} \mathrm{DM}$. These values were above those found by S. S. Oliveira et al. (2020) for Paiaguas palisadegrass silage $\left(531.5 \mathrm{~g} \mathrm{~kg}^{-1}\right.$ DM) and below those found for grain sorghum silage (663.5 $\mathrm{g} \mathrm{kg}^{-1} \mathrm{DM}$ ). The difference in the contents above is due to the sorghum hybrid; sweet sorghum has a lower number of grains in the panicle than grain sorghum and provides less energy as a result (Taveira et al., 2020). TDN is an important parameter for animal feed since energy and protein are often the most limiting factors for ruminants (L. B. D. Oliveira et al., 2010).

It is worth mentioning that the nutritional quality of the silage remained practically unchanged throughout the fermentation process (Figures 1, 2 and 3); the final results were similar to those observed in the fresh material before ensiling (Table 1). This shows that the materials were adequately ensiled and that the harvesting time and material chopping, storage, compaction and sealing processes were satisfactory and maintained the levels of available nutrients in the silage.

At all addition levels, the silages showed good nutritional quality. Similar results were obtained by several authors studying the silage of sorghum with tropical forages (R. F. Costa et al., 2016a; M. G. Ribeiro et al., 2017; S. S. Oliveira et al., 2020). These results show the importance of producing mixed silages to balance the nutritional value of silages, which can be an effective alternative to improve the quality of the pure sorghum silage.

\section{Conclusion}

The inclusion of Paiaguas palisadegrass and Ipypora grass in sorghum silage raised the $\mathrm{pH}$, buffering capacity and $\mathrm{NH}_{3}-\mathrm{N}$ content of the silages and reduced their dry matter content but did not negatively affect their fermentation characteristics, which remained within appropriate limits.

Increasing the level of Paiaguas palisadegrass or Ipypora grass in the silage increased the crude protein content, IVDMD and mineral matter content of the silage and decreased the fibre fraction (NDF, ADF, lignin) and ether extract contents. Adding tropical 
forages to sorghum silage material at levels above $40 \%$ is recommended.

Among forage crops, the addition of Paiaguas palisadegrass to sorghum silage resulted in higher content of crude protein and IVDMD.

Mixed silages can be an effective alternative to improve the quality of exclusive sweet sorghum silage.

\section{Acknowledgments}

The authors would like to thank the Instituto Federal Goiano for financially supporting this study.

\section{References}

Association Official Analytical Chemists (1990). Official methods of analysis (15nd ed.). Arlington, VA: AOAC.

Behling Neto, A. B., Reis, R. H. P., Cabral, L. S., Abreu, J. G., Sousa, D. P., Pedreira, B. C., \& Carvalho, A. P. S. (2017). Fermentation characteristics of different purpose sorghum silage. Semina: Ciências Agrárias, 38(4, Supl. 1), 2607-2618. doi: 5433/1679-0359.2017v38n4Supl1p2607

Bolsen, K. K., Lin, C., Brent, B. E., Feyerherm, A. M., Urban, J. E., \& Aimutis, W. R. (1992). Effect of silage additives on the microbial succession and fermentation process of alfalfa and corn silages. Journal of Dairy Science, 75(11), 3066-3083. doi: 10.3168/ jds.S0022-0302(92)78070-9

Bueno, A. V. I., Lazzari, G., Jobim, C. C., \& Daniel, J. L. P. (2020). Ensiling total mixed ration for ruminants: a review. Agronomy, 10(6), 879. doi: 10.3390/agronomy 10060879
Cappelle, E. R., Valadares, S. D. C., Fo., Silva, J. F. C. D., \& Cecon, P. R. (2001). Estimativas do valor energético a partir de características químicas e bromatológicas dos alimentos. Revista Brasileira de Zootecnia, 30(6), 1837-1856. doi: 10.1590/S1516-35982 001000700022

Chen, L., Dong, Z., Li, J., \& Shao, T. (2019). Ensiling characteristics, in vitro rumen fermentation, microbial communities and aerobic stability of low-dry matter silages produced with sweet sorghum and alfalfa mixtures. Journal of the Science of Food and Agriculture, 99(5), 2140-2151. doi: 10. 1002/jsfa.9406

Costa, N. R., Andreotti, M., Crusciol, C. A. C., Pariz, C. M., Lopes, K. S. M., Leonardo de Almeida Yokobatake, K.,... Souza, D. M. de. (2016b). Effect of intercropped tropical perennial grasses on the production of sorghum-based silage. Agronomy Journal, 108(6), 2379-2390. doi: 10.2134/ agronj2016. 07.0385

Costa, R. F., Pires, D. A. D. A., Moura, M. M. A., Sales, E. C. J. D., Rodrigues, J. A. S., \& Rigueira, J. P. S. (2016a). Agronomic characteristics of sorghum genotypes and nutritional values of silage. Acta Scientiarum. Animal Sciences, 38(2), 127133. doi: 10.4025/actascianimsci.v38i2. 29567

Costa, R. R. G. F., Costa, K. A. P. de, Souza, W. F. de, Epifanio, P. S., Santos, C. B., Silva, J. T. da, \& Oliveira, S. S. (2018). Production and quality of silages pearl millet and Paiaguas palisadegrass in monocropping and intercropping in different forage systems. Bioscience Journal, 34(2), 357-367. doi: 10.14393/BJ-v34n2a2018-33843 
Cruvinel, W. S., Costa, K. A. D. P., Teixeira, D. A. A., Silva, J. T. da, Epifanio, P. S., Costa, P. H. C. P., \& Fernandes, P. B. (2017). Fermentation profile and nutritional value of sunflower silage with Urochloa brizantha cultivars in the off-season. Revista Brasileira de Saúde e Produção Animal, 18(2), 249-259. doi: 10.1590/s1519-99402017000200004

Cruz, S. S. D., Andreotti, M., Pascoaloto, I. M., Lima, G. C. D., \& Soares, C. D. A. (2020). Produção de sorgo forrageiro consorciado com gramíneas e guandu-anão no corte da safra. Revista Ciência Agronômica, 51(2), 1-10. doi: 10.5935/1806-6690.20200031

Daniel, J. L. P., Bernardes, T. F., Jobim, C. C., Schmidt, P., \& Nussio, L. G. (2019). Production and utilization of silages in tropical areas with focus on Brazil. Grass and Forage Science, 74(2), 188-200. doi: $10.1111 /$ gfs. 12417

Echeverria, J. R., Euclides, V. P. B., Sbrissia, A. F., Montagner, D. B., Barbosa, R. A., \& Nantes, N. N. (2016). Acúmulo de forragem e valor nutritivo do híbrido de Urochloa BRS RB331 Ipyporã sob pastejo intermitente. Pesquisa Agropecuária Brasileira, 51(7), 880-889. doi: 10.1590/S0100-204X2016 000700011

Epifanio, P. S., Costa, K. A. P. de, Costa Severiano, E. da, Souza, W. F. de, Teixeira, D. A. A., Silva, J. T. da, \& de Moura Aquino, M. (2019). Productive and nutritional characteristics of Brachiaria brizantha cultivars intercropped with Stylosanthes cv. Campo Grande in different forage systems. Crop and Pasture Science, 70(8), 718-729. doi: 10.1071/CP18447

Euclides, V. P. B., Nantes, N. N., Montagner, D. B., Araújo, A. R. D., Barbosa, R. A., Zimmer,
A. H., \& Valle, C. B. D. (2018). Beef cattle performance in response to Ipyporã and Marandu Brachiaria grass cultivars under rotational stocking management. Revista Brasileira de Zootecnia, 47(1), 1-10. doi: 10. $1590 /$ rbz4720180018

Ferreira, D. D. J., Zanine, A. D. M., Lana, R. D. P., Souza, A. L. de, Negrão, F. M., Geron, L. J., \& Dantas, C. C. (2016). Kinetic parameters of ruminai degradation of Marandu grass silage supplemented with brewer's grain. Ciencia e Investigación Agraria, 43(1), 135142. doi: $10.4067 /$ S0718-16202016000 00012

Gomes, A. L. M., Jacovaci, F. A., Bolson, D. C., Nussio, L. G., Jobim, C. C., \& Daniel, J. L. P. (2019). Effects of light wilting and heterolactic inoculant on the formation of volatile organic compounds, fermentative losses and aerobic stability of oat silage. Animal Feed Science and Technology, 247(1), 194-198. doi: 10.1016/j.anifeedsci. 2018.11.016

Gomes-Rocha, F. M., Evangelista, A. R., Rocha, N. S., Silva, T. O. D., Abreu, L. R. A., Ortêncio, M. O.,... Bonfá, C. S. (2018). Fermentation characteristics and bromatological composition of sweet sorghum bagasse silages. Revista Brasileira de Saúde e Produção Animal, 19(2), 157-165. doi: 10. 1590/s1519-99 402018000200002

Jobim, C. C., Nussio, L. G., Reis, R. A., \& Schmidt, P. (2007). Avanços metodológicos na avaliação da qualidade da forragem conservada. Revista Brasileira de Zootecnia, 36, 101-119. doi: 10.1590/S15 16-35982007001000013

Kung, L., Jr., Shaver, R. D., Grant, R. J., \& Schmidt, R. J. (2018). Silage review: interpretation 
of chemical, microbial, and organoleptic components of silages. Journal of Dairy Science, 101(5), 4020-4033. doi: 10.3168/ jds.2017-13909

Marafon, F., Neumann, M., Carletto, R., Lima Wrobel, F. de, Mendes, E. D., Spada, C. A., \& Faria, M. V. (2015). Características nutricionais e perdas no processo fermentativo de silagens de milho, colhidas em diferentes estádios reprodutivos com diferentes processamentos de grãos. Semina: Ciências Agrárias, 36(2), 917-931. doi: 10.5433/1679-0359.2015v36n2p917

McDonald, P. J., Henderson, A. R., \& Heron, S. J. E. (1991). The biochemistry of silage (2nd ed.), Edinburgh, UK. Mallow Chalcombe Publications.

Mertens, D. R. (2002). Gravimetric determination of amylase-treated neutral detergent fiber in feeds with refluxing in beakers or crucibles: collaborative study. Journal of AOAC international, 85(6), 1217-1240. doi: 10.1093/jaoac/85.6.1217

Negrão, F. D. M., Zanine, A. D. M., Souza, A. L. D., Cabral, L. D. S., Ferreira, D. D. J., \& Dantas, C. C. O. (2016). Perdas, perfil fermentativo e composição química das silagens de capim Brachiaria decumbens com inclusão de farelo de arroz. Revista Brasileira de Saúde e Produção Animal, 17(1), 13-25. doi: 10.1590/S1519-9940 2016000100002

Oliveira, L. B. D., Pires, A. J. V., Carvalho, G. G. P. D., Ribeiro, L. S. O., Almeida, V. V. D., \& Peixoto, C. A. D. M. (2010). Perdas e valor nutritivo de silagens de milho, sorgosudão, sorgo forrageiro e girassol. Revista Brasileira de Zootecnia, 39(1), 61-67. doi: 10.1590/S1516-35982010000100008
Oliveira, S. S., Costa, K. A. P. de, Souza, W. F. de, Santos, C. B. dos, Teixeira, D. A. A., \& Costa, V. (2020). Production and quality of the silage of sorghum intercropped with Paiaguas palisadegrass in different forage systems and at different maturity stages. Animal Production Science, 60(5), 694704. doi: 10.1071/AN17082

Paludo, F., Costa, K. A. P., Dias, M. B. C., Santos, F. A., Silva, A. C. G., Rodrigues, L. G.,... Muniz, M. P. (2020). Fermentative profile and nutritive value of corn silage with Tamani guinea grass. Semina: Ciências Agrárias, 41(6), 2733-2746. doi: 10.5433/1679-0359.2020v41n6p2733

Quintino, A. D. C., Abreu, J. G., Almeida, R. G., Macedo, M. C. M., Cabral, L. D. S., \& Galati, R. L. (2016). Valor nutritivo de silagem de capim-piatã em monocultivo e em consórcio com sorgo de corte e pastejo. Ciência Animal Brasileira, 17(2), 185-191. doi: 10.1590/1089-6891v17i219107

Ribeiro, L. S. O., Pires, A. J. V., Carvalho, G. G. P.D., Santos, A. B. D., Ferreira, A. R., Bonomo, P., \& Silva, F. F. D. (2010). Composição química e perdas fermentativas de silagem de canade-açúcar tratada com ureia ou hidróxido de sódio. Revista Brasileira de Zootecnia, 39(9), 1911-1918. doi: 10.1590/S1516-35 982010000900008

Ribeiro, M. G., Costa, K. A. P., Souza, W. F. D., Cruvinel, W. S., Silva, J. T. D., \& Santos, D. R. D., Jr. (2017). Silage quality of sorghum and Urochloa brizantha cultivars monocropped or intercropped in different planting systems. Acta Scientiarum. Animal Sciences, 39(3), 243-250. doi: 10. 4025/actascianimsci.v39i3.33455 
Santos, H. G., Jacomine, P. K. T., Anjos, L. H. C., Oliveira, V. A., Lumbreras, J. F., Coelho, M. R.,... Cunha, T. J. F. (2018). Sistema brasileiro de classificação de solos (5a ed.). Brasília: EMBRAPA Solos.

Skonieski, F. R., Nornberg, J. L., Azevedo, E. B. de, David, D. B. de, Kessler, J. D., \& Menegaz, A. L. (2010). Produção, caracterização nutricional e fermentativa de silagens de sorgo forrageiro e sorgo duplo propósito. Acta Scientiarum. Animal Sciences, 32(1), 27-32. doi: 10.4025/actascianimsci.v32i1. 7200

Souza, W. F., Costa, K. A. P., Guarnieri, A., Severiano, E. C., Silva, J. T., Teixeira, A. A., \& Dias, M. B. C. (2019). Production and quality of the silage of corn intercropped with Paiaguas palisadegrass in different forage systems and maturity stages. Revista Brasileira de Zootecnia, 48. doi: 10.1590/rbz4820180222

Taveira, J. H. S., Costa, K. A. P. de, Aquino, M. M. de, Silva, C. V. da, Souza, W. F. de, Dias, M. B. C. de, \& Pereira, A. D. (2020). Fermentation parameters and quality of sweet and biomass sorghum silages with doses of vinasse. Journal of Agricultural Studies, 8(3), 678-692. doi: 10.5296/jas. v8i3.16 823
Teetor, V. H., Duclos, D. V., Wittenberg, E. T., Young, K. M., Chawhuaymak, J., Riley, M. R., \& Ray, D. T. (2011). Effects of planting date on sugar and ethanol yield of sweet sorghum grown in Arizona. Industrial Crops and Products, 34(2), 1293-1300. doi: 10.1016/j.indcrop.2010.09.010

Tilley, J. M. A., \& Terry, D. R. (1963). A two-stage technique for the in vitro digestion of forage crops. Grass and Forage Science, 18(2), 104-111. doi: 10.1111/j.1365-2494. 1963.tb00335.x

Van Soest, P. J. (1994). Nutritional ecology of the ruminant (2nd ed.). Ithaca: Cornell University Press.

Zhang, S. J., Chaudhry, A. S., Ramdani, D., Osman, A., Guo, X. F., Edwards, G. R., \& Cheng, L. (2016). Chemical composition and in vitro fermentation characteristics of high sugar forage sorghum as an alternative to forage maize for silage making in Tarim Basin, China. Journal of Integrative Agriculture, 15(1), 175-182. doi: 10.1016/S20953119(14)60939-4 
